- FINANSE I PRAWO FINANSOWE.

- Journal of Finance and Financial Law

Wrzesień/September 2019 • vol. 3(23): 49-62

http://dx.doi.org/10.18778/2391-6478.3.23.04

\title{
ROLA I ZNACZENIE PODATKÓW JAKO JEDNEGO ZE ŹRÓDEŁ DOCHODÓW BUDŻETU PAŃSTWA
}

\author{
Magdalena Lubaś \\ Uniwersytet Jagielloński
}

\begin{abstract}
Streszczenie
Obecnie nikt nie wyobraża za sobie gospodarki bez podatków. Każdy człowiek konsumuje, korzysta z rozmaitych usług, osiąga dochód z różnych źródeł, posiada nieruchomość. To właśnie te wymienione czynności, jak i szereg innych, stanowią podstawę opodatkowania, od której to pobierany jest stosowny podatek w odpowiedniej kwocie. Celem artykułu jest wskazanie znaczenia podatku w finansowaniu państwa oraz wzrostu wpływów do budżetu państwa z podatków na przestrzeni lat. Wskazano jaką część budżetu państwa stanowią podatki oraz zaprezentowano sposoby wykorzystywania przez organy państwowe i samorządowe tego rodzaju danin. W tym celu posłużono się analizą danych zastanych zaprezentowanych na stronie Ministerstwa Finansów.
\end{abstract}

Słowa kluczowe: podatek, budżet państwa, dochód, jednostka samorządu terytorialnego.

JEL Class: H24, H26, H3. 


\section{WPROWADZENIE}

$\mathrm{Na}$ gruncie polskiego ustawodawstwa podatek jest definiowany jako publiczno-prawne, nieodpłatne, przymusowe oraz bezzwrotne świadczenie pieniężne na rzecz Skarbu Państwa, województwa powiatu lub gminy, wynikające z ustawy podatkowej [art. 6 Ustawy z dnia 29 sierpnia 1997 r..., Dz.U. 1997, nr 137, poz. 926]. Pobieranie podatku przez państwo stanowi jedno z najważniejszych źródeł dochodu budżetu każdego państwa. Świadczy to o sile państwa, niezależności oraz zdolności do swobodnego działania i swobodnego rozwoju. Podatki należą do jednych z najważniejszych instrumentów efektywnej polityki gospodarczej państwa [Makowicz 2004: 91 i nast.]. Celem artykułu jest wskazanie znaczenia podatku w finansowaniu państwa oraz wzrostu wpływów do budżetu państwa $\mathrm{z}$ podatków na przestrzeni lat. $\mathrm{W}$ tym celu posłużono się analizą danych zastanych zaprezentowanych na stronie Ministerstwa Finansów.

W niniejszym artykule przedstawione zostaną najważniejsze podatki z punktu widzenia budżetu państwa. Omówione zostanie ich znaczenie, przedmiot, jak i podmiot opodatkowania, stawka oraz skala w konkretnym podatku oraz dochody uzyskane przez Skarb Państwa z danej daniny.

Praca została podzielona na pięć części. Pierwsza z nich, jest wprowadzeniem prezentującym problematykę omawianego tematu, cel, strukturę opracowania. Część drugą stanowi prezentację historii podatków na poziomie globalnym. Opisano w niej w jaki sposób ewoluował na przestrzeni wieków system podatkowy. W kolejnej części został zaprezentowany budżet państwa, jego założenia oraz sposób kształtowania się dochodów. Czwartym etapem opracowania jest omówienie podatków, które odgrywają największą rolę w budżecie państwa. Wskazano podstawę prawną każdego z podatku, zakres podmiotowy i przedmiotowy oraz dane wskazujące wysokość dochodów z poszczególnych podatków w wybranych latach. W ostatniej części zostały zaprezentowane wnioski płynące $\mathrm{z}$ artykułu.

\section{HISTORIA PODATKÓW}

Podatki nie są domeną XX czy XXI w. Swoje źródła mają już w starożytności. Wówczas podatki i daniny nakładano tylko na niektóre grupy społeczne. Podatek był uiszczany w rozmaitych formach, np.: rolnicy oddawali na rzecz państwa część zbiorów, rzemieślnicy oddawali część wyrobów, zaś kupcy daniny z osiągniętych zysków. Na skutek podbojów i szybkiego wzrostu bogactwa Rzymian, podatek w 167 roku p.n.e. został zniesiony.

W średniowieczu zmalała rola podatków. Miało to miejsce głównie za sprawą tego, że władcy utrzymywali się w dużej mierze z posiadanych ziem, przywilejów 
monarszych oraz ceł. Mimo znikomej roli podatków w tym okresie wyróżnia się takie publiczne świadczenia jak: dziesięcina - podatek religijny w chrześcijaństwie i judaizmie, pańszczyzna - praca na roli chłopów na rzecz władcy, świętopietrze danina na rzecz papiestwa, myto - opłata za przewożone towary.

W XV w. nastąpił rozwój systemu podatkowego we Francji i Anglii. Jednak dopiero w XIX w. odnotowuje się wzrost obciążeń podatkowych oraz uznania podatków za element instrumentów finansowych.

Podatki początkowo wcale nie stanowiły danin na rzecz państwa, przez długi czas były płacone na rzecz osoby sprawującej władzę. Grupą społeczną, którą najczęściej obciążano dodatkowymi świadczeniami, byli przedstawiciele narodu żydowskiego. W Polsce XV w. za sprawą przyznanych przez władców przywilejów szlachcie, grupa ta uzyskała realną możliwość ustalania wysokości podatku jak i zakresu. W dawnej Polsce funkcjonowały trzy podstawowe rodzaje podatków: tzw. poradlany, pogłówny oraz podymny. Podatek podymny był pobierany od każdego domu mieszkalnego, a jego wysokość była ustalana w zależności od wielkości budynku i miasta. Od końca XVIII w. kwota tego podatku była naliczana od ilości ustawionych na dachu kominów.

Przełomowym momentem w kształtowaniu się polskiego systemu podatkowego, było ustanowienie przedwojennej ordynacji podatkowej z 15 marca 1934 r. Ten akt normatywny stanowi dziś punkt wyjścia do obecnie stosowanych rozwiązań. Po raz pierwszy na świecie podatek od osób fizycznych wprowadzono we Francji w 1954 roku [Kuzińska 2002: 15].

\section{BUDŻET PAŃSTWA}

Mianem budżetu państwa w literaturze przedmiotu określa się plan finansowy sporządzany przez obóz rządzący na okres roku budżetowego, który w większość państw jest tożsamy z rokiem kalendarzowym (wyjątek stanowi np. budżet państwa w Wielkiej Brytanii - swój początek ma w kwietniu, zaś w Stanach Zjednoczonych - w październiku). Przywołany plan finansowy jest podstawą prawną do pobierania dochodów i planowania wydatków. Podstawą do sporządzenia projektu ustawy budżetowej na kolejny rok budżetowy stanowi Wieloletni Plan Finansowy Państwa, który jest sporządzany na dany rok budżetowy, jak i trzy następne lata przez ministra właściwego ds. finansów.

Wyróżnia się dwie metody sporządzania budżetu państwa (zob. rys. 1).

Dochody budżetu państwa to nie tylko podatki. Do budżetu wpływają liczne wpływy, m.in.:

- podatki i opłaty, w części, która zgodnie z odrębnymi ustawami nie stanowi dochodów jednostek samorządu terytorialnego, przychodów państwowych funduszy celowych oraz innych jednostek sektora finansów publicznych; 


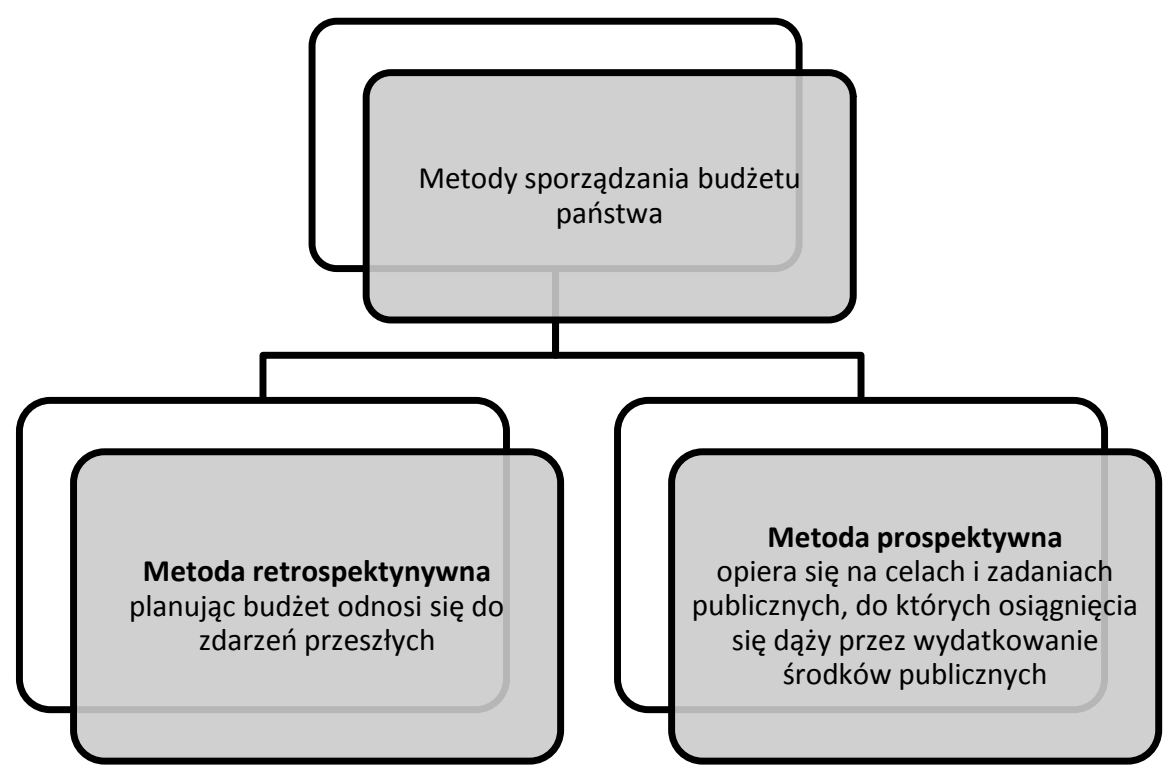

Rys. 1. Metody sporządzania budżetu państwa

Źródło: opracowanie własne.

- cła;

- wpłaty z zysku przedsiębiorstw państwowych oraz jednoosobowych spółek Skarbu Państwa;

- wpłaty z tytułu dywidendy;

- wpłaty z zysku Narodowego Banku Polskiego;

- wpłaty nadwyżki środków finansowych agencji wykonawczych;

- dochody pobierane przez państwowe jednostki budżetowe, o ile odrębne ustawy nie stanowią inaczej;

- dochody z najmu i dzierżawy oraz z innych umów o podobnym charakterze, dotyczące składników majątkowych Skarbu Państwa, o ile odrębne ustawy nie stanowią inaczej;

- odsetki od środków zgromadzonych na rachunkach bankowych państwowych jednostek budżetowych lub organów władzy publicznej, o ile odrębne ustawy nie stanowią inaczej;

- odsetki od lokat terminowych ustanowionych ze środków zgromadzonych na centralnym rachunku bieżącym budżetu państwa;

- odsetki od udzielonych z budżetu państwa pożyczek krajowych i zagranicznych; 
- grzywny, mandaty i inne kary pieniężne, o ile odrębne ustawy nie stanowią inaczej;

- spadki, zapisy i darowizny w postaci pieniężnej na rzecz Skarbu Państwa [Art. 111 Ustawy z dnia 27 sierpnia 2009 r..., Dz.U. 2017, poz. 2077].

W polskim systemie finansowym istnieją również przychody, które nie stanowią dochodu. Zalicza się do nich: przychody zwrotne - osiągane przez zaciąganie długu publicznego oraz wpływy z prywatyzacji. Do ich cechy charakterystycznej należy to, że przychody te zwiększają zasoby środków pieniężnych, które mogą wykorzystywać jednostki sektora finansów publicznych lecz nie powiększają jej majątku, istnieje konieczność w przyszłości zwrotu otrzymanych środków [Malinowska-Misiąg i Misiąg 2006: 141].

\section{Założenia budżetu państwa}

Przed rozpoczęciem każdego roku finansowego rząd przygotowuje projekt ustawy budżetowej. W projekcie wskazuje się założenia dotyczące dochodów budżetu państwa wraz ze źródłami z których mają one pochodzić oraz wydatki $\mathrm{z}$ ich przeznaczeniem na konkretne obszary działalności państwowej.

Tabela 1. Dochody i wydatki budżetu państwa (przyjęte założenia w ustawie budżetowej)

\begin{tabular}{|c|c|c|c|c|c|}
\hline $\begin{array}{c}\text { Wyszczególniane } \\
\text { pozycje }\end{array}$ & 2015 & 2016 & 2017 & 2018 & $\begin{array}{c}2019 \\
\text { (dane z projek- } \\
\text { tu budżetu } \\
\text { państwa) }\end{array}$ \\
\hline $\begin{array}{c}\text { Dochody budżetu } \\
\text { państwa }\end{array}$ & $289,1 \mathrm{mld} \mathrm{zł}$ & $314,7 \mathrm{mld} \mathrm{zł}$ & $350,5 \mathrm{mld} \mathrm{zł}$ & $355,7 \mathrm{mld} \mathrm{zł}$ & $386,9 \mathrm{mld} \mathrm{zł}$ \\
\hline $\begin{array}{c}\text { Wydatki budżetu } \\
\text { państwa }\end{array}$ & $331,7 \mathrm{mld} \mathrm{zł}$ & $360,9 \mathrm{mld} \mathrm{zł}$ & $375,9 \mathrm{mld} \mathrm{zł}$ & $397,2 \mathrm{mld} \mathrm{zł}$ & $415,4 \mathrm{mld} \mathrm{zł}$ \\
\hline
\end{tabular}

Źródła: opracowanie własne na podstawie danych dostępnych Ministerstwa Finansów [www3].

Z tabeli 1 wynika, że w każdym z pięciu przedstawionych lat dochody budżetu państwa przewyższają wydatki, tworząc $w$ ten sposób tzw. deficyt budżetowy. Według założeń zawartych w ustawie budżetowej na koniec 2018 roku deficyt będzie wynosił 42,5 mld złotych. Pod koniec 2019 roku deficyt w porównaniu z końcem wcześniejszego roku zmniejszy się o 14 mld złotych. 


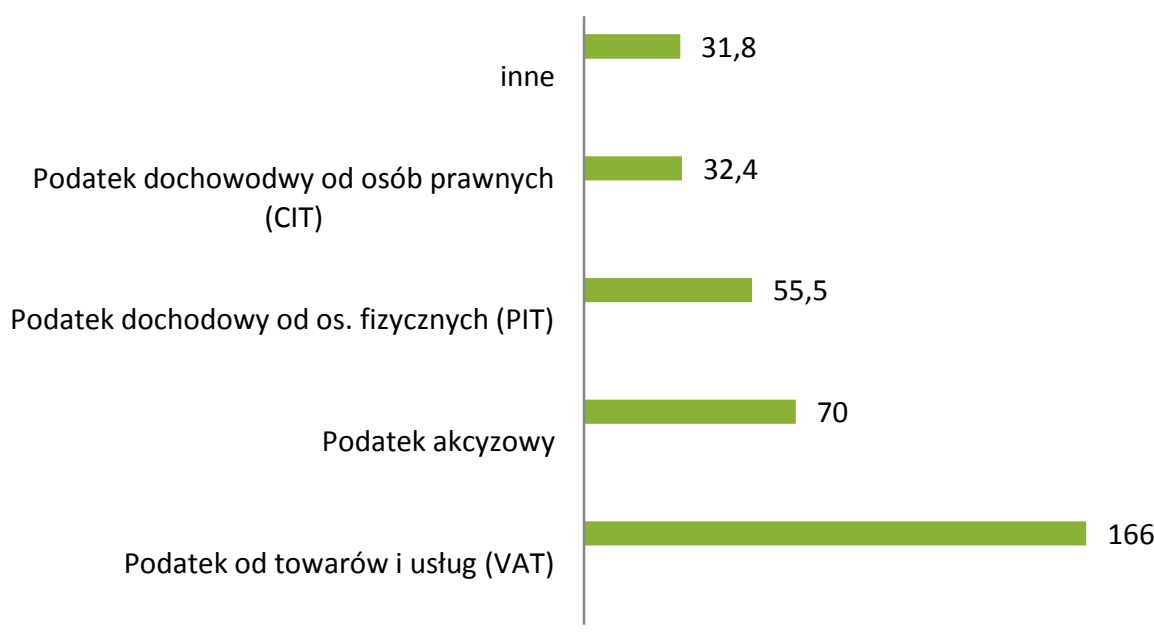

Wykres 1. Projekt budżetu państwa na 2018 r. - dochody [w mld zł]

Źródło: opracowanie własne na podstawie: Ministerstwo Finansów, „Projekt ustawy budżetowej na 2018 rok" [dostęp: styczeń 2019 r.].

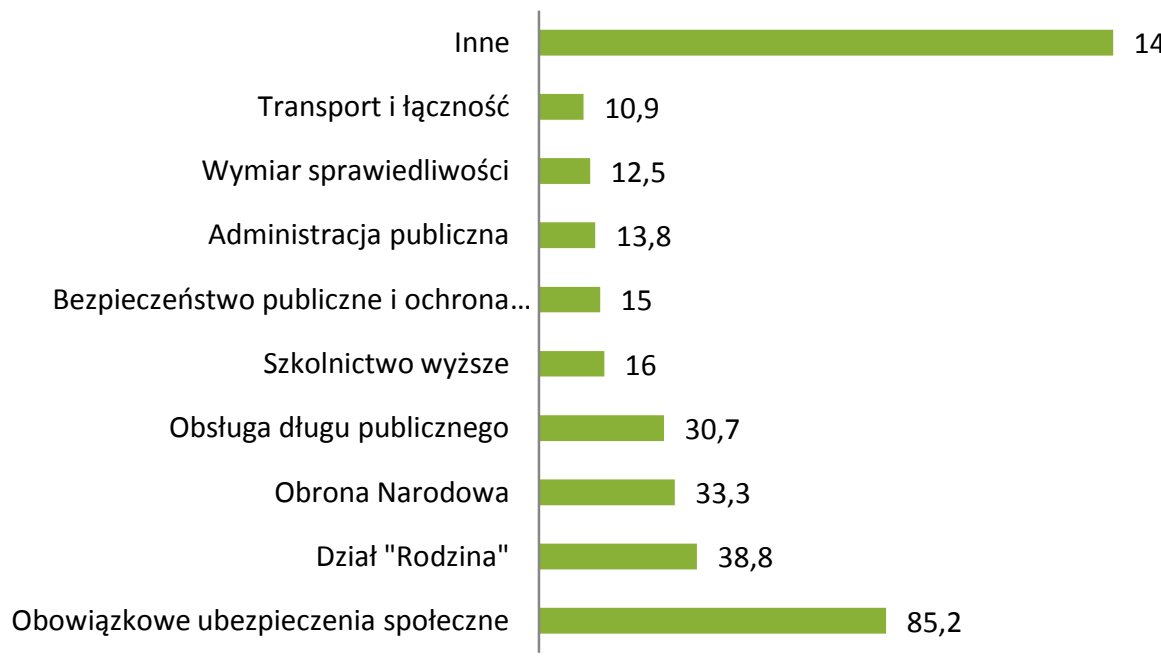

Wykres 2. Projekt budżetu państwa na 2018 r. - wydatki [w mld zł]

Źródło: opracowanie własne na podstawie: Ministerstwo Finansów, „Projekt ustawy budżetowej na 2018 rok" [dostęp: styczeń 2019 r.]. 
Wykres 1 i 2 przedstawia strukturę dochodów oraz wydatków budżetu państwa w 2018 roku. W największej mierze dochody jakie są prognozowane pochodzą z podatków. Głównym źródłem zasilającym są dochody z podatków obrotowych (VAT oraz akcyza). Państwo osiąga również duże zasoby pieniężne z podatków dochodowych od osób fizycznych i prawnych. Na kategorię „inne” w przedstawionej prognozie dochodów składają się środki z Unii Europejskiej, a także dochody uzyskiwane m.in. z mienia Skarbu Państwa, udzielonych poręczeń i gwarancji, spadków, darowizn itd. Jak wynika z wykresu 2 najwięcej państwo wydaje na obowiązkowe ubezpieczenia społeczne oraz wszelkie programy rządowe, działania związane z obronnością oraz innymi sektorami gospodarki.

\section{PODATKI W POLSCE}

Od lat dziewięćdziesiątych XX w. prawo podatkowe w Polsce zyskało na znaczeniu. Miało to miejsce na skutek zmian systemowych zachodzących w kraju, które odegrały wielką rolę w systemie finansowym i gospodarczym [Głuchowski i Patyk 2011: 8]. Wprowadzenie w 1991 r. ustawy o podatku dochodowym od osób fizycznych oraz w 1992 roku ustawy o podatku dochodowym od osób prawnych pozwoliło na tworzenie nowego systemu podatkowego, który jest dostosowany do wymagań XXI w.

\subsection{Podatek dochodowy od osób fizycznych - PIT}

Na gruncie polskiego ustawodawstwa podatek dochodowy od osób fizycznych jest regulowany ustawą o podatku dochodowym od osób fizycznych z 1991 roku. Obowiązek podatkowy nałożony jest $\mathrm{w}$ tym podatku na osoby fizyczne, osobowe spółki handlowe oraz przedsiębiorstwo w spadku [Art. 1 Ustawy z dnia 26 lipca 1991 r..., Dz.U. 1991, nr 80, poz. 350]. Opodatkowanie spółek osobowych nie jest ujednolicone w obecnie obowiązujących systemach podatkowych, co stwarza trudności $\mathrm{w}$ funkcjonowaniu międzynarodowego prawa podatkowego, zwłaszcza w obszarze postanowień umów o unikaniu podwójnego opodatkowania [Mastalski 2016: 412]. Opodatkowaniu tym podatkiem podlegają wszelkiego rodzaju dochody poza wskazanymi przez ustawodawcę zwolnieniami i wyłączeniami [Art. 9.11 Ustawy z dnia 26 lipca 1991 r..., Dz.U. 1991, nr 80, poz. 350]. Uzyskane przez podatnika przychody pomniejsza się o koszty uzyskania przychodu a więc te, które zostały poniesione w celu osiągnięcia, zachowania lub zabezpieczenia źródła przychodu [Art. 221 Ustawy z dnia 26 lipca 1991 r..., Dz.U. 1991, nr 80, poz. 350]. Kwotę dochodu można pomniejszyć o zapłacone składki na ubezpieczenia społeczne, wpłaty na indywidu- 
alne konto zabezpieczenia emerytalnego, wydatki na cele rehabilitacyjne poniesione przez podatnika będącego osobą niepełnosprawną lub na którego utrzymaniu są osoby niepełnosprawne, wydatki na użytkowanie sieci Internet oraz darowizny np.: na organizacje społeczne czy kult religijny [Art. 261 Ustawy z dnia 26 lipca 1991 r..., Dz.U. 1991, nr 80, poz. 350].

W podatku dochodowym od osób fizycznych ustawodawca zastosował stawkę progresywną szczeblową. Jeżeli podstawa obliczania podatku jest niższa niż 85528 zł stosuję się stawkę 18\%, powyżej przywołanej kwoty zastosowanie ma stawka $32 \%$.

Podatek dochodowy od osób fizycznych stanowi dochód budżetu państwa, samorządy mają w nim swój udział - gminy na poziomie 37,98\%, natomiast partycypuje w $10,25 \%$. Tabela 2 przedstawia wpływy z podatku dochodowego od osób fizycznych w latach 2015-2018.

Tabela 2. Wpływy z podatku dachowego od osób fizycznych w latach 2015-2018

\begin{tabular}{|c|c|c|c|}
\hline 2015 & 2016 & 2017 & 2018 \\
\hline $83 \mathrm{mld} \mathrm{zł}$ & $89 \mathrm{mld} \mathrm{zł}$ & $98 \mathrm{mld} \mathrm{zł}$ & $\begin{array}{c}\text { brak danych na dzień } \\
08.06 .2019 \mathrm{r} .\end{array}$ \\
\hline
\end{tabular}

Źródło: opracowanie własne na podstawie danych na stronie www4 [dostęp: 13.01.2019].

Jak pokazują dane zaprezentowane w tab. 2 z każdym rokiem wpływy z podatku dochodowego od osób fizycznych wzrastają. W 2017 roku w porównaniu do 2015 roku wpływy wzrosły o $16 \%$.

\subsection{Podatek dochodowy od osób prawnych - CIT}

Podatek dochodowy od osób prawny reguluje ustawa z 15 lutego 1992 roku o podatku dochodowym od osób prawnych. Podatek swym zakresem obejmuje osoby prawne, spółki kapitałowe w organizacji, jednostki organizacyjne niemające osobowości prawnej z wyjątkiem spółek niemających osobowości prawnej, spółki komandytowo-akcyjne oraz podatkową grupę kapitałową [Art. 1 Ustawy z dnia 15 lutego 1992 r..., Dz. U. 1992, nr 21, poz. 86]. Jeżeli podatnicy mają na terytorium Rzeczypospolitej Polskiej siedzibę i zarząd, obowiązek podatkowy obejmuje całość ich dochodów bez względu w jakim miejscu zostały one osiągnięte. W sytuacji gdy podatnik nie ma siedziby lub zarządu na terytorium Rzeczypospolitej obowiązek podatkowy obejmuje wyłącznie dochody osiągnięte na terytorium RP [Art. 3 Ustawy z dnia 15 lutego 1992 r..., Dz. U. 1992, nr 21, poz. 86]. Przedmiotem opodatkowania tym podatkiem objęte są przychody lub dochody [Maruchin 2011: 90]. W podatku dochodowym od osób prawnych wy- 
różnia się dwa rodzaje przychodów: z działalności gospodarczej oraz z udziałów w zyskach osób prawnych. Od 1 stycznia 2019 r. stawka podatkowa dla małych podatników i podatników rozpoczynających działalność w roku podatkowym, w którym rozpoczęli działalność wynosi 9\%. Do 31 grudnia 2018 roku, dla wymienionych wyżej podmiotów obowiązywała stawka w wysokości $15 \%$. Tabela 3 przedstawia wpływy z podatku dochodowego od osób prawnych w latach 2015-2018.

Tabela 3. Wpływy z podatku dochodowego od osób fizycznych w latach 2015-2018

\begin{tabular}{|c|c|c|c|}
\hline 2015 & 2016 & 2017 & 2018 \\
\hline $30 \mathrm{mld} \mathrm{zł}$ & $34 \mathrm{mld} \mathrm{zł}$ & $38 \mathrm{mld} \mathrm{zł}$ & $\begin{array}{c}\text { brak danych na dzień } \\
08.06 .2019 \mathrm{r} .\end{array}$ \\
\hline
\end{tabular}

Źródło: opracowanie własne na podstawie danych na stronie www4 [data dostępu 13.01.2019].

Według dostępnych danych dochody z podatku od osób prawnych w 2016 roku zostały w skali 101,2\% planu na rok 2016 r. oraz 102,2 \% dochodów realizowanych w 2015 r. [www2, dostęp: 13.01.2019].

\subsection{Podatek od towarów i usług - VAT}

Od wieków podatki obrotowe wykorzystuje się jako jedno z głównych źródeł finansowania wydatków państwowych, szczególnie w wyniku wzmożonych potrzeb budżetów na skutek wojen i kryzysów [Pomorska i in. 2003: 9].

Na gruncie polskiego ustawodawstwa podatek od towarów i usług jest regulowany ustawą z dnia 11 marca 2004 roku o podatku od towarów i usług. Jest to podatek obrotowy charakteryzujący się następującymi cechami: podatek pobierany jest na wszystkich etapach obrotu aż do nabycia przez konsumenta (podatek wielofazowy), ciężar ekonomiczny podatku obciąża konsumenta a nie producenta, podlega potrąceniu i zwrotowi, jest zharmonizowany z prawem Unii Europejskiej. VAT jest zaliczany do podatków pośrednich. Podatek od towarów i usług swoim zakresem przedmiotowym obejmuje m.in. odpłatną dostawę towarów i odpłatne świadczenie usług na terytorium krajów, eksport towarów, import towarów, wewnątrzwspólnotową dostawę towarów czy wewnątrzwspólnotowe nabycie towarów [Art. 5 Ustawy z dnia 11 marca 2004 r..., Dz.U. 2004, nr 54, poz. 535]. Podatnik podatków od towaru i usług ma prawo pomniejszania podatku należnego o podatek naliczony, jaki zapłacił wcześniej w cenie dóbr nabytych na potrzeby prowadzenia działalności gospodarczej [Art. 865 Ustawy z dnia 11 marca 2004 r..., Dz.U. 2004, nr 54, poz. 535]. Z uwagi na swoją kon- 
strukcję, podatek od towarów i usług jest narzędziem masowych przestępstw gospodarczych, polegających przede wszystkim na wyłudzeniu jego zwrotu w literaturze przedmiotu tego typu zachowania określa się mianem przestępstw karuzelowych. Przestępcy bardzo często wprowadzają do obiegu gospodarczego faktury, które mają za zadanie dokumentować fikcyjnie dokonane czynności. Mianem przywołanych wcześniej przestępstw karuzelowych określa się tworzone przez oszustów struktury pozorującej przepływ towarów pomiędzy państwami Unii Europejskiej, służącej wyłudzeniu podatku.

Według raportów Najwyższej Izby Kontroli, wynika, że tylko w 2015 r. państwo polskie straciło ok. 80 mld zł na wyłudzaniu podatku od towarów i usług [Informacje o wynikach kontroli Najwyższej Izby Kontroli, 2014]. Jednak według najnowszych raportów NIK z czerwca 2018 roku wynika, że wzrosła skuteczność organów podatkowych w aspekcie walki z wyłudzeniami w zakresie podatku VAT.

Tabela 4. Wpływy z podatku dochodowego z podatku VAT w latach 2015-2018

\begin{tabular}{|c|c|c|c|}
\hline 2015 & 2016 & 2017 & 2018 \\
\hline $123 \mathrm{mld} \mathrm{zł}$ & $127 \mathrm{mld} \mathrm{zł}$ & $157 \mathrm{mld} \mathrm{zł}$ & $174,9 \mathrm{mld} \mathrm{zł}$ \\
\hline
\end{tabular}

Źródło: opracowanie własne na podstawie danych na stronie www4 [dostęp: 13.01.2019].

W 2017 r. dochody z podatku od towarów i usług wzrosły o 24\% w porównaniu w rokiem ubiegłym, czyli o 30 mld zł wpłynęło więcej do budżetu państwa niż w 2016 r. Było to efektem dobrej koniunktury, ale też wprowadzonych zmian i narzędzi, które poprawiły jego ściągalność.

Wpływy z podatku od towarów i usług stanowią podstawowe źródło dochodów budżetu państwa. Ponad 40\% pieniędzy w budżecie państwa pochodzi właśnie z podatku VAT. Jak wynika z wykresu 1 wpływu z VAT z roku na rok rosną. Dzieje się to m.in. na skutek uszczelnienia przepisów prawa podatkowego m.in. wprowadzenia obowiązku comiesięcznego przesyłania przez podatników informacji o prowadzonej ewidencji zakupu i sprzedaży VAT w postaci jednolitego pliku kontrolnego (JPK _VAT) czy wprowadzenia tzw. pakietu paliwowego, wzmożonej kontroli organów podatkowych, czy wprowadzenia licznych narzędzi informatycznych.

\subsection{Podatek akcyzowy}

Podatek akcyzowy jest regulowany przez ustawę o podatku akcyzowym z dnia 6 grudnia 2008 roku. Ważne znaczenie odgrywają również trzy dyrektywy w sprawie harmonizacji struktur poszczególnych produktów akcyzowych. Pobór akcyzy jest zharmonizowany na szczeblu Unii Europejskiej. W ustawodawstwie 
unijnym położono duży nacisk na ujednolicenie zasad opodatkowania trzech grup wyrobów takich jak: wyroby energetyczne, alkohol i tytoń. Podatek akcyzowy uznaje się za świadczenie selektywne, ponieważ obciąża tylko określone towary (wyroby akcyzowe) oraz na gruncie polskiego ustawodawstwa samochody osobowe [Art. 8 Ustawy z dnia 6 grudnia 2008 r..., Dz.U. 2009, nr 3, poz. 11]. Podatek akcyzowy w zakresie przedmiotowym obciąża co do zasady towary cechujące się wysoką akumulacją zysku - tzn. koszt wytworzenia tych produktów jest niski, przy czym przychody ze sprzedaży tych produktów są bardzo wysokie [Jasińska, data dostępu: 13.01.2019]. Podatnikami podatku akcyzowego są co do zasady osoby fizyczne, osoby prawne oraz jednostki organizacyjne nieposiadające osobowości prawnej, które dokonują czynności podlegających opodatkowaniu lub wobec których zaistniał stan faktyczny podlegający opodatkowaniu [Art. 13 Ustawy z dnia 6 grudnia 2008 r..., Dz.U. 2009, nr 3, poz. 11]. Podstawę opodatkowania akcyzą stanowi obrót wyrobami akcyzowymi. Podobnie jak w podatku od towarów i usług, akcyza nie jest integralną częścią ceny, ale jest doliczana do czystej ceny [Wolański 2007: 164]. Tabela 5 przedstawia wpływy z podatku akcyzowego w latach 2015-2018.

Tabela 5. Wpływy z podatku akcyzowego osób fizycznych w latach 2015-2018

\begin{tabular}{|c|c|c|c|}
\hline 2015 & 2016 & 2017 & 2018 \\
\hline $63 \mathrm{mld} \mathrm{zł}$ & $66 \mathrm{mld} \mathrm{zł}$ & $68 \mathrm{mld} \mathrm{zł}$ & $70 \mathrm{mld} \mathrm{zł}$ \\
\hline
\end{tabular}

Źródło: opracowanie własne na podstawie danych na stronie www4 [data dostępu 13.01.2019].

W 2016 r. dochody z tytułu podatku akcyzowego wyniosły $65,7 \mathrm{mld}$ zł i stanowiły $102,6 \%$ prognozy ustawy budżetowej.

W 2017 roku do budżetu państwa z podatku akcyzowego wpłynęły dochody w wysokości 68,8 mld zł, z czego 18,8 mld zł wpłynęło od samych wyrobów tytoniowych. Większy dochód w podatku akcyzowym od wyrobów tytoniowych jest osiągany $\mathrm{z}$ paliw silnikowych - ok. $46 \%$ akcyzy [www1, dostęp: 13.01.2019].

\subsection{Podatek bankowy}

W Polsce od 1 lutego 2016 roku w gospodarce zaczął obowiązywać podatek od niektórych instytucji finansowych regulowany ustawą z dnia 15 stycznia 2016 roku. Podatnikami tego podatkami są instytucje finansowe, takie jak banki krajowe, oddziały banków zagranicznych, oddziały instytucji kredytowych, spółdzielcze kasy oszczędnościowo-kredytowe, krajowe zakłady ubezpieczeń 
i reasekuracji, oddziały oraz główne oddziały zagranicznych zakładów ubezpieczeń i reasekuracji, czy instytucje pożyczkowe [Art. 4 Ustawy z dnia 15 stycznia 2016 r..., Dz.U. 2016, poz. 68]. Podstawą opodatkowania jest nadwyżka sumy wartości aktywów podatnika, wynikająca z zestawienia obrotów i sald, ustalonego na ostatni dzień miesiąca na podstawie zapisów na kontach księgi głównej. Wartość nadwyżki zawiera się w przedziale między 4 mld zł a $200 \mathrm{mln}$ zł. Kwota będąca podstawą opodatkowania jest zależna od konkretnego podmiotu, na który nałożony jest obowiązek podatkowy. Podatek wynosi $0,0366 \%$ podstawy opodatkowania [Art. 7 Ustawa z dnia 15 stycznia 2016 r..., Dz.U. 2016, poz. 68].

W innych krajach europejskich już w pierwszej dekadzie XXI wieku wprowadzono podatek obciążający sektor bankowy, m.in. w Szwecji, na Węgrzech i nieco później w Austrii, Słowenii, Wielkiej Brytanii itd. [Furman 2017: 75]. Obecnie obowiązuje w 21 z 28 Państwach Unii Europejskiej.

Dochody uzyskane w 2016 r. (w przedziale czasowym od marca do grudnia) wyniosły ponad $3,5 \mathrm{mld}$ zł, co stanowiło ok. $64 \%$ prognozy przyjętej w ustawie budżetowej na rok 2016 oraz 1,1\% dochodów budżetu państwa. W 2017 r. dochody z podatku wyniosły ponad $4,34 \mathrm{mld}$ zł, co stanowiło $110 \%$ przyjętego założenia oraz $1,3 \%$ dochodów budżetu państwa [Informacja o wynikach kontroli przeprowadzonej przez Najwyższą Izbę Kontroli, 2018]. 85,5\% dochodu z podatku od niektórych instytucji finansowych przysporzyły budżetowi państwa banki krajowe, 15,8\% krajowe zakłady ubezpieczeń, a $0,7 \%$ pozostałe podmioty podatku wymienione w ustawie.

\section{PODSUMOWANIE}

Bez podatków państwo nie jest w stanie sfinansować licznych wydatków. To właśnie podatki są głównym źródłem zasilającym budżet, czego powodzi powyższa analiza. Wraz ze wzrostem dochodów osiąganych $\mathrm{z}$ tego źródła maleje deficyt budżetowy. Wzmożone kontrole sprawdzające prawidłowość realizowania obowiązku podatkowego powodują wzrost dochodów w budżecie właśnie z podatków. Pomimo licznych narzekań w związku z wysokością kwot jakie podatnicy muszą odprowadzać warto zwrócić uwagę na przeznaczenie tych pieniędzy oraz realizację celu jakim one służą.

Przeprowadzona analiza danych zastanych wskazuje na wzrost $\mathrm{z}$ roku na rok wpływu do budżetu państwa pochodzących z podatków. Wydatki, które ponosi państwo finansując je w dużej mierze $\mathrm{z}$ podatków wskazują na znaczenie tego typu danin w sprawnym funkcjonowaniu państwa.

Ciekawym poznawczo byłoby dokonanie analizy jak się przedstawia wpływ $\mathrm{z}$ podatków $\mathrm{w}$ innych państwach oraz zestawienie tych danych ze sobą $\mathrm{w}$ celu dokonania porównań i analizy. 


\title{
BIBLIOGRAFIA
}

Furman Ł, 2017, Podatek od aktywów instytucji finansowych - zagrożenia czy korzyści, „Zeszyty Naukowe Małopolskiej Wyższej Szkoły Ekonomicznej w Tarnowie”, t. 33, nr 1, marzec.

Głuchowski J., Patyk J., 2011, Zarys polskiego prawa podatkowego Wydanie 3, LexisNexis, Warszawa.

Informacja o wynikach kontroli przeprowadzonej przez Najwyższą Izbę Kontroli, 2018, Pobór podatku od instytucji finansowych.

Jasińska P, Podatki, WWW.Prezydent.Pl.

Kuzińska H., 2002, Rola podatków pośrednich w Polsce, Wydawnictwo Wyższej Szkoły Przedsiębiorczości i Zarządzania im. Leona Koźmińskiego, Warszawa.

Makowicz B., 2004, Harmonizacja podatków pośrednich w Uni Europejskiej, Studia Europejskie, nr 2.

Malinowska-Misiąg E., Misiąg W, 2006, Finanse Publiczne w Polsce, LexisNexis, Warszawa.

Maruchin W., 2011, System podatkowy, Wyższa Szkoła Finansów i Zarządzania w Warszawie, Warszawa.

Mastalski R., 2016, Prawo Podatkowe, Wydawnictwo C.H. Beck, Warszawa.

Pomorska A., Szołno-Koguc J. Wójtowicz K., 2003, Procesy dostosowania polskich podatków pośrednich do standardów Unii Europejskiej, Wydawnictwo Uniwersytetu Marii CurieSkłodowskiej, Lublin.

Ustaw z dnia 26 lipca 1991 r. o podatku dochodowym od osób fizycznych, Dz.U. 1991, nr 80, poz. 350 .

Ustawa z dnia 15lutego 1992r.o podatku dochodowym od osób prawnych, Dz.U. 1992, nr 21, poz. 86.

Ustawa z dnia 29 sierpnia 1997 r. - Ordynacja podatkowa, Dz.U. 1997, nr 137, poz. 926.

Ustawa z dnia 11 marca 2004 r. o podatku od towarów i usług, Dz.U. 2004, nr 54, poz. 535.

Ustawa z dnia 6 grudnia 2008 r. o podatku akcyzowym, Dz.U. 2009, nr 3, poz. 11.

Ustawa z dnia 27 sierpnia 2009 r. o finansach publicznych, Dz.U. 2017, poz. 2077.

Ustawa z dnia 15 stycznia 2016 r. o podatku od niektórych instytucji finansowych, Dz.U. 2016, poz. 68 .

Wolański R., 2007, System podatkowy w Polsce, Wolters Kluwer Polska, Warszawa.

[www1] https://businessinsider.com.pl/wiadomosci/branza-tytoniowa-wplywy-do-budzetupanstwa-z-akcyzy/xbxc2mg.

[www2] https://businessinsider.com.pl/wiadomosci/dochody-w-2016-roku-ile-z-pit-ile-zakcyzy/r509lew [dostęp: 13.01.2019].

[www3] www.mf.gov.pl.

[www4] www.nik.gov.pl.

\section{THE ROLE AND IMPORTANCE OF TAXES AS ONE OF THE SOURCES OF STATE BUDGET INCOME}

\begin{abstract}
At present, no one can imagine an economy without taxes. Everyone consumes, uses various services, achieves income from various sources owns property. It is these listed activities and a number of others that form the basis of taxation, from which a relevant tax is charged in
\end{abstract}


an appropriate amount. The purpose of the article is to indicate the importance of tax in financing the state and the increase of revenues to the state budget from taxes over the years. It indicates what part of the state budget is tax and how the state and local government bodies used this type of tax. For this purpose, an analysis of the existing data presented on the website of the Ministry of Finance has been used.

Keywords: tax, state budget, income, local government. 